\title{
Effectiveness of Teams Teaching-Hybrid Learning (TTHL) in Higher Education
}

\author{
Kholilur Rahman ${ }^{1}$, Abdul Hamid Wahid ${ }^{2}$, Irfan Afandi ${ }^{3}$, Muhammad Mushfi El Iq Bali ${ }^{4}$, \\ Lukman Hakim ${ }^{5}$ \\ Tarbiya Faculty, IAI Ibrahimy, Genteng, Banyuwangi, Indonesia ${ }^{1}$ \\ Islamic Faculty, Nurul Jadid University, Paiton, Probolinggo, Indonesia ${ }^{2}$ \\ Tarbiya Faculty, IAI Ibrahimy, Genteng, Banyuwangi, Indonesia ${ }^{3}$ \\ Islamic Faculty, Nurul Jadid University, Paiton, Probolinggo, Indonesia ${ }^{4}$ \\ Syari'ah Faculty, IAI Ibrahimy, Genteng, Banyuwangi, Indonesia ${ }^{5}$ \\ \{lilur66@gmail.com ${ }^{1}$, hamidw@gmail.com ${ }^{2}$, irfan.edu26@gmail.com ${ }^{3}$, \\ mushfieliqbali8@gmail.com ${ }^{4}$,1973elha@gmail.com $\left.{ }^{5}\right\}$
}

\begin{abstract}
This study aims to determine the significance of differences in the lecture process before and after implementing Team Teaching-Hybrid Learning (TTHL). This research was conducted at Nurul Jadid University Paiton Probolinggo and IAI Ibrahimy Genteng Banyuwangi. The study population was all third-semester students of Nurul Jadid University Paiton Probolinggo and IAI Ibrahimy Genteng Banyuwangi with education statistics courses. The research sample was purposive sampling technique. Quantitative research using the quasiexperimental method uses non-equivalent control group design with the TTHL pre-test and post-test treatment. Instrument data collection in the form of observations, closed questionnaires, tests, and documentation. Data analysis techniques using descriptive analysis and hypothesis testing include Manova test and t-test. Testing the hypothesis prerequisites using the normality test (Column of Smirnov) and homogeneity test (Box's Manova). The results showed that from multivariate testing with Sig. (p) $0.000<0.05$ which means the first hypothesis $(\mathrm{H} 1)$ is accepted. TTHL is also proven to be effective in improving learning outcomes as evidenced by the comparison of the mean values of increase (significance) of the experimental class and the control class which have a difference in the value of 14.57 with the advantages of the experimental group (24.26: 9.69). In addition, the results of the hypothesis test obtained the Sig. (p) equal to $0.017<0.05$ which means the second hypothesis $(\mathrm{H} 1)$ is accepted.
\end{abstract}

Keywords: Team Teaching, Hybrid Learning, Higher education.

\section{Introduction}

During this time, in general, the learning strategies developed in educational institutions tended to be done solitary [1]. Management of learning is the responsibility of educators individually, both in planning, implementation, and assessment learners' learning [2]. When faced with the demands of a very complex curriculum and real conditions that are not conducive, educators often become powerless and have limitations to be able to implement 
curriculum objectives. The solution, Team Teaching strategies can be used as an alternative to overcome the problems faced by educators.

Team Teaching is one form of learning strategy that involves two educators or more in the learning process of students, with a clear and balanced division of roles and responsibilities [3]. Through the Team Teaching strategy, it is expected that partners can work together and complement each other in managing the learning process. Every problem that arises in the learning process can be overcome together.

The development of information technology has encouraged the emergence of various learning model innovations in the field of education. The innovative learning models themselves appear as alternative solutions to overcome various obstacles to traditional learning methods [4]. One application of information technology in the field of education is the development of hybrid learning. The hybrid learning system combines two types of choices which will play the lead role in the lecture process: instructor-led or learner-led [5]. In general, the initial stage of applying the led-instructor is then when the lecture process is running, change it to student-led.

\section{Literature review}

\subsection{Team Teaching}

Team Teaching is a learning strategy whose learning process activities are carried out by more than one educator with the division of their respective roles and responsibilities [6]. The teaching team that presents lesson material with the team teaching strategy presents the same teaching material at the same time and purpose. The educators together prepare, implement, and evaluating student learning outcomes. The learning process can be done a rotation with the lecture method or together with the panel discussion method.

The concept of team teaching sounds ideal. Both instructors can work together to achieve a common goal of advancing students' academic performance; 'two for one, agreement' from the world of teaching [6]. Teaching teams is an effective way to build deep conceptual learning while learning alternative ways to teach the same subject matter. The central purpose of co-generative dialogue is to further develop an existing understanding of the teaching situation to enhance professional growth [7].

The requirements for effective teaching depend on collective knowledge and a wealth of diverse perspectives, so call for the need to collaborate and work with the team of lecturers. The process of dialogue between lecturers creates a clash of thoughts, which has the potential to revitalize students' teaching abilities. Simultaneously, this will stimulate students to take the enthusiasm of the lecturers who can help to challenge, expand and enrich their understanding $[8]$.

Table 1. Steps to Team Teaching

\begin{tabular}{lll}
\hline Planning & $\begin{array}{l}\text { Learning } \\
\text { Planning }\end{array}$ & $\begin{array}{l}\text { Preparation of RPS (Semester Lecture Plans) is } \\
\text { carried out together with partners so that they agree } \\
\text { with the content and target competencies of the } \\
\text { planned learning process. }\end{array}$ \\
\cline { 2 - 3 } & $\begin{array}{l}\text { Learning methods that will be used must also be } \\
\text { planned together with partners so that the learning } \\
\text { process flow becomes directed. }\end{array}$ \\
\hline
\end{tabular}




\begin{tabular}{|c|c|c|}
\hline & $\begin{array}{l}\text { Learning } \\
\text { Materials }\end{array}$ & $\begin{array}{l}\text { Team Teaching members must both understand the } \\
\text { content of the material and the competencies that } \\
\text { will be achieved and mastered by students in order } \\
\text { to complement each other's lack of knowledge of } \\
\text { each member. }\end{array}$ \\
\hline & $\begin{array}{l}\text { Roles and } \\
\text { Responsibilities }\end{array}$ & $\begin{array}{l}\text { The division of roles and responsibilities must be } \\
\text { clear according to the abilities of each educator. }\end{array}$ \\
\hline \multirow[t]{2}{*}{ Implementation } & $\begin{array}{ll}\text { Semi } & \text { Team } \\
\text { Teaching } & \end{array}$ & $\begin{array}{l}\text { One of the educators acts as a speaker in full } \\
\text { lecture hours, and one person as a team supervisor } \\
\text { or assistant. }\end{array}$ \\
\hline & $\begin{array}{ll}\text { Full } & \text { Team } \\
\text { Teaching } & \end{array}$ & $\begin{array}{l}\text { Team Teaching members take turns as presenters } \\
\text { in full lecture hours, meaning the lecture hours are } \\
\text { divided into two. }\end{array}$ \\
\hline \multirow[t]{2}{*}{ Evaluation } & $\begin{array}{l}\text { Educator } \\
\text { Evaluation }\end{array}$ & $\begin{array}{l}\text { The educator's evaluation during the learning } \\
\text { process was carried out by Team Teaching partners } \\
\text { after the lecture hour ended. Evaluation takes the } \\
\text { form of constructive criticism and suggestions that } \\
\text { are carried out outside the classroom. }\end{array}$ \\
\hline & $\begin{array}{l}\text { Student } \\
\text { Evaluation }\end{array}$ & $\begin{array}{l}\text { Team Teaching together determines the method of } \\
\text { evaluation and preparation of evaluation questions. }\end{array}$ \\
\hline
\end{tabular}

\subsection{Hybrid Learning}

Hybrid learning is defined as a coherent design approach that integrates the power of faceto-face and online learning to address valuable educational goals [9]. Hybrid learning is a learning strategy for integrating innovation and technological progress through an online learning system with the interaction and participation of traditional learning strategies.

This strategy has the potential to enrich students' learning and make teaching and resource allocation more efficient but poses several challenges; one is that students' ability to establish social presence in synchronous hybrid learning strategies [10]. Social presence has proven to be very important for course satisfaction, students' involvement, community development inquiry and student learning outcomes [11].

The implementation of hybrid learning depends on several factors, namely: (1) Facilities and infrastructure covering the internet network, (2) Professional development of educators in accessing ICTs, (3) Students need to be equipped with the knowledge to access computers and the internet in implementing hybrid learning. The following types of hybrid learning are:
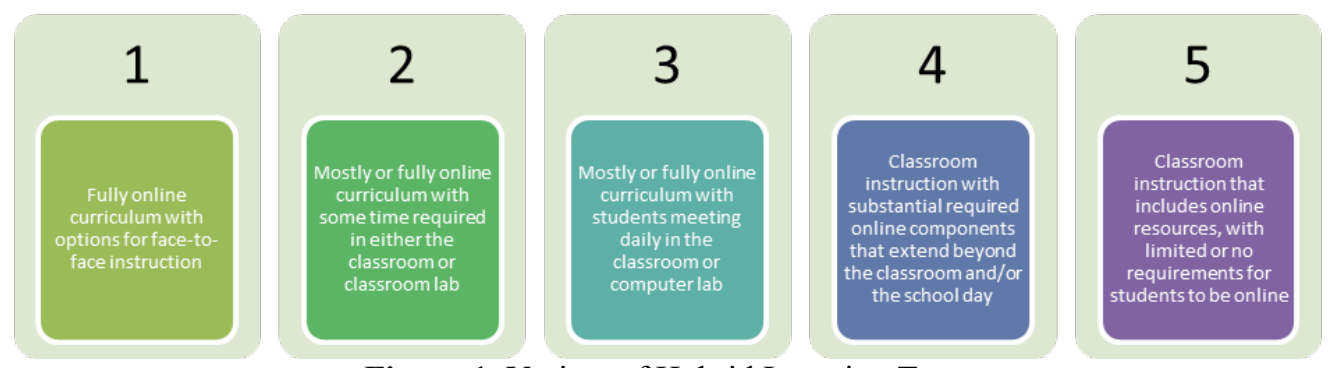

Figure 1. Variety of Hybrid Learning Types 


\subsection{Team Teaching-Hybrid Learning in Higher Education}

The stages of team teaching are initiated by planning the learning process [12], that is, by making a semester lecture plan, determining learning methods, and sharing roles which are all done together. After the planning phase is complete, team teaching will carry out the learning process in the classroom according to their respective roles. At the end of team, teachinglearning provides a question of evaluation to students. After the learning process ends, team teaching conducts evaluations outside the classroom regarding the learning process.

Classroom management is also carried out by team teaching to create a conducive learning environment and control it when there is a disruption in learning. Team teaching may be utilized to form a better understanding of the educational settings and learners [13].

Critical thinking and problem-solving are significant to the quality of higher education programs. A hybrid strategy of course delivery addresses these needs with a face to face component and an online component [14]. The implementation of hybrid learning is designed according to campus conditions. The implementation of hybrid learning that uses full internet facilities requires students and lecturers to always stand-by on the internet. Lecture activities are conducted via the internet, for example, video conferencing. But the instruction is carried out face to face. While the implementation of hybrid learning uses semi-internet facilities or sometimes, meaning that not every lecture meeting uses the internet. Internet access is used when carrying out examinations or collecting assignments in the form of research papers or reports.

\section{Method}

This research was conducted at Nurul Jadid University Paiton Probolinggo and IAI Ibrahimy Genteng Banyuwangi in the Odd Semester of the 2018-2019 academic year. The population in this study were all students of Nurul Jadid University Paiton Probolinggo and IAI Ibrahimy Genteng Banyuwangi in the third semester with Education Statistics courses as many as 1,596 students. The research sample was purposive sampling technique (1 experimental class and one control class) each of the 45 students with details of 30 Nurul Jadid University Paiton Probolinggo students and 15 IAI Ibrahimy Genteng Banyuwangi students. This research is a quantitative study with a quasi-experimental method that was carried out using a non-equivalent control group design with pre-test before treatment and post-test after the treatment of Team Teaching-Hybrid Learning (TTHL). Instrument data collection in the form of observations, closed questionnaires, tests, and documentation. Data analysis techniques using descriptive analysis and hypothesis testing include Manova test and t-test. Testing the hypothesis prerequisites using the normality test (Column of Smirnov) and homogeneity test (Box's Manova).

\section{Result and discussion}

The results of the study showed that there were differences in learning outcomes of student Education Statistics before and after learning.

Table 2. Average Value of Learning Outcomes in Educational Statistics of Semester III Students

\begin{tabular}{|c|c|c|c|}
\hline Group & Pretest & Posttest & Significance \\
\hline
\end{tabular}




\begin{tabular}{crrr}
\hline Experimentation & 65.52 & 89.78 & 24.26 \\
\hline Control & 61.94 & 71.63 & 9.69 \\
\hline
\end{tabular}

The average score obtained by the experimental class before treatment worth 65.52 increased to 89.78 , while the control class 61.94 increased to 78.63. The effectiveness of Team Teaching-Hybrid Learning (TTHL) in the experimental class of 24.26 showed significant results compared to the control class worth 9.69. The following are the details of the classification of learning outcomes of Educational Statistics in the experimental class and the control class before and after treatment.

Table 3. Learning Outcomes of Educational Statistics Before and After Treatment

\begin{tabular}{cccccccccc}
\hline \multirow{2}{*}{ Criteria } & \multirow{2}{*}{$\begin{array}{l}\text { Value } \\
\end{array}$} & Range & \multicolumn{3}{c}{ Before Treatment } & \multicolumn{4}{c}{ After treatment } \\
\cline { 3 - 10 } & & Experimentation & Control & Experimentation & Control \\
\cline { 3 - 10 } & $22-35.5$ & 0 & 0.0 & 0 & 0.0 & 0 & 0.0 & 0 & 0.0 \\
\hline Very Less & $22-6$ & F & $\%$ & F & $\%$ & F & $\%$ \\
\hline Less & $35.6-49.1$ & 0 & 0.0 & 0 & 0.0 & 0 & 0.0 & 0 & 0.0 \\
\hline Enough & $49.2-62.7$ & 8 & 14.4 & 17 & 37.8 & 4 & 6.8 & 7 & 15.5 \\
\hline Good & $62.8-76.3$ & 19 & 44.5 & 22 & 48.9 & 20 & 45.9 & 26 & 57.8 \\
\hline Very Good & $76.4-90$ & 18 & 41.1 & 6 & 13.3 & 21 & 47.1 & 12 & 26.7 \\
\hline \multicolumn{2}{c}{ Total } & 45 & 100.0 & 45 & 100.0 & 45 & 100.0 & 45 & 100.0 \\
\hline
\end{tabular}

Manova test results obtained Sig. (p) $0.000<0.05$ concluded that Team TeachingHybrid Learning (TTHL) proved to be effective in improving student learning outcomes. The results of the t-test obtained the value of Sig. (p) equal to $0.017<0.05$ so it can be concluded that there are differences in the increase in the learning outcomes of the third semester Education Statistics of Nurul Jadid University Paiton Probolinggo students and IAI Ibrahimy Genteng Banyuwangi significant.

\section{Conclusion}

Based on the results of the study, it was concluded that the application of the Team Teaching-Hybrid Learning (TTHL) proved effective in improving the learning outcomes of the third semester Education Statistics of Nurul Jadid University Paiton Probolinggo and IAI Ibrahimy Genteng Banyuwangi. Shown from multivariate testing with Sig. (p) $0.000<0.05$ which means the hypothesis (H1) is accepted. Furthermore, the Team Teaching-Hybrid Learning (TTHL) strategy also proved effective in improving the learning outcomes of the third semester Education Statistics of Nurul Jadid University Paiton Probolinggo and IAI Ibrahimy Genteng Banyuwangi. This is evidenced by the comparison of the average value of increase (significance) of the experimental class and the control class which has a difference in the value of 14.57 with the superiority of the experimental group (24.26: 9.69). Also, the results of the hypothesis test obtained the Sig. (p) Equal to $0.017<0.05$ which means the hypothesis (H1) is accepted. Thus, it can be stated that there are differences in the application of Teaching-Hybrid Learning (TTHL) Teams and improvement in learning outcomes Education Statistics of the third-semester students of Nurul Jadid University Paiton Probolinggo and IAI Ibrahimy Genteng Banyuwangi which have proven significant effectiveness. 


\section{References}

[1] S. A. Hasan Baharun, "Curriculum Development Through Creative Lesson Plan," Cendikia, vol. 16, no. 1, pp. 41-62, 2018.

[2] M. M. E. I. Bali, Strategi Pembelajaran Pendidikan Agama Islam. Probolinggo: Pustaka Nurja, 2018.

[3] H. Baharun, "Penerapan Pembelajaran Active Learning untuk Meningkatkan Hasil Belajar Siswa di Madrasah,” J. Pendidik. Pedagog., vol. 1, no. 1, pp. 34-46, 2015.

[4] L. M. Jeffrey, J. Milne, G. Suddaby, and A. Higgins, "Blended Learning: How Teachers Balance the Blend of Online and Classroom Components," J. Inf. Technol. Educ., vol. 13, pp. 121-140, 2014.

[5] C. Muali, S. Islam, and M. M. E. I. Bali, "Free Online Learning Based On Rich Internet Applications; The Experimentation Of Critical Thinking About Student Learning Style," J. Phys. Conf. Ser., vol. 1114, pp. 1-6, 2018.

[6] H. F. Carley, "Team Teaching Styles Utilized In Japan: Do They Really Work?," J. Int. Educ. Res., vol. 9, no. 3, pp. 247-252, 2013.

[7] S. J. Jang, "Research on the Effects of Team Teaching Upon Two Secondary School Teachers," Educ. Res., vol. 48, no. 2, pp. 177-194, 2006.

[8] N. Yu Jin, M. A. bin A. Tarmizi, A. Halim, and A. A. Karim, "Team Teaching in Higher Education: The Relationship Between Team Norms and Effectiveness," Int. J. Arts Commer., vol. 1, no. 1, pp. 1-15, 2014.

[9] F. Movahedzadeh, "Improving Student Success Through Hybrid Mode of Delivery in Nonscience Major Biology Classes," Education, vol. 2, no. 7, pp. 333-339, 2012.

[10] B. W. Gleason and C. Greenhow, "Hybrid Learning in Higher Education: The Potential of Teaching and Learning with Robot-Mediated Communication," Online Learn., vol. 21, no. 4, pp. 159-176, 2017.

[11] M. M. E. I. Bali, "Model interaksi sosial dalam mengelaborasi keterampilan sosial," Pedagog. J. Pendidik. Islam, vol. 4, no. 2, pp. 211-227, 2017.

[12] M. W. and I. M. Syaiful Islam, Hasan Baharun, Chusnul Muali, Moh. Idil Ghufron, Mushfi el Iq Bali, "To Boost Students' Motivation and Achievement through Blended Learning," J. Phys. Conf. Ser., vol. 1114 01204, pp. 1-11, 2018.

[13] J. T. Avella, M. Kebritchi, S. G. Nunn, and T. Kanai, "Learning Analytics Methods, Benefits, and Challenges in Higher Education: A Systematic Literature Review," Online Learn., vol. 20, no. 2, pp. 13-29, 2016.

[14] S. Meyers and L. D. Feeney, "Examining Interactive and Metacognitive Processes in Student Learning: Findings from a Hybrid Instructional Environment," $J$. Asynchronous Learn. Netw., vol. 20, no. 3, pp. 110-125, 2016. 